\title{
Research on the Construction of Network Culture Working Team in Colleges and Universities
}

\author{
Xing Nian \\ Shaanxi University of Chinese Medicine, Xianyang, China, 712046
}

Keywords: colleges and universities; network culture; talent team building

\begin{abstract}
With the rapid development of Internet information technology, the status of network in campus life of college students is becoming more and more important. Under such circumstances, it is very necessary for colleges and universities to build their own network culture. In the process of network culture construction, the construction of talent team is very important. However, there are still some problems to be improved in the construction of network culture working teams in Chinese universities. Only by solving these problems can we guarantee the smooth progress of the construction of network culture working team in colleges and universities, and promote the rapid development of college network culture.
\end{abstract}

Colleges and universities shoulder the important task of training high-quality talents for the country, and shoulder heavy responsibilities. With the rapid development of Internet technology, all kinds of information are rapidly disseminated in the campus. Under such circumstances, colleges and universities must strengthen their own network culture construction, and form and develop their own characteristic network culture on campus. In the process of network culture construction, the high-quality network culture working team can play an irreplaceable role. Under such circumstances, if colleges and universities want to carry forward their own campus network culture, it is essential to build a high-quality network culture construction team. However, at the present stage, there are still a series of problems, such as the imperfect system of the system, the lack of maturity of the theoretical research, and so on. If colleges and universities want to strengthen their own network culture working team, these problems shall be solved effectively.

\section{The Importance of Network Culture Construction in Colleges and Universities}

With the rapid development of Internet information technology, Internet culture has become a very popular term. In fact, the lack of Internet culture has been unprecedented development. In daily life and work, people are more accustomed to getting all kinds of information they need from the Internet media. However, when we see that the Internet brings convenience to people, we can not ignore the negative impact of the openness of the network. Since the release of information on the network is not strictly audited, the current network is filled with some false, vulgar, and even reactionary information, which has a very negative impact on people's thoughts. Students in Colleges and universities are in the shaping stage of world outlook, outlook on life and values, and are more vulnerable to these bad information. In order to ensure the healthy growth of college students, it is imperative to purify the network environment. However, purification of the network environment will inevitably lead to "vacuum" to some extent. Under such circumstances, colleges and universities should speed up their own network culture construction and fill the "vacuum" with excellent network culture. Only in this way can students avoid the negative influence of bad information on the Internet, and ensure that colleges and universities can cultivate qualified socialist successors. In the construction of network culture in small colleges and universities, due to the lack of professional network personnel, the process of network culture construction in many colleges and universities in China is slow and has not played a due role. In view of this, colleges and universities must speed up the construction of the talent team in the network culture work, and ensure the healthy development of the campus network culture construction with high-quality professional network talents [1]. 


\section{The Current Situation of the Construction of Network Culture in Chinese Colleges and Universities}

For colleges and universities, the importance of building a high-quality network culture work team is beyond doubt. Unfortunately, most universities in China do not really realize the importance of the construction of network culture teams at this stage. In this case, the construction and operation system of the campus network culture has not been established, which is also an important reason for the construction of the network culture work team in China's colleges and universities at the present stage. Because of this, at present, the construction of network cultural work teams in Chinese universities is progressing slowly and even stagnating. The reason for this is that the leadership of the university has not realized the role of the high-quality talent team in the construction of network culture, which leads to the perfunctory work in the selection and appointment of network cultural workers. The quality of the selected network culture workers can not be guaranteed. In some colleges and universities, network culture workers have not been regarded as the important teachers of the school. Therefore, the network cultural workers who work in this kind of colleges and universities are often treated unfairly, and their wages, welfare and activities are lack of effective guarantee, and it is difficult to get equal status with other teachers. In this case, the network culture workers in Colleges and universities are difficult to have enough enthusiasm to work, and can not devote themselves to the construction of campus network culture, which leads to the slow construction of network culture in Colleges and universities [2].

Compared with other works, the construction of network culture needs more professional theoretical research, and the process of research is very long. In the long process of research, scientific theoretical guidance is indispensable. Under such circumstances, colleges and universities want to ensure the effectiveness of network culture construction, so we must master the development rule and uniqueness of Internet culture. In the course of the study, we can draw on and absorb the advanced experience of other universities or research institutions at home and abroad, and make scientific supplement and development according to the actual situation of this school, so as to guarantee the quality of the construction of network culture in Colleges and universities. But in the actual network culture construction, the relevant educational departments do not attach much importance to this aspect. At the same time, because of the construction of network culture in a short time it is difficult to see high returns, so the enthusiasm of the construction of network culture in Colleges and universities is also generally not high. Under such circumstances, the effect of network culture construction will be greatly reduced. What we must see is that in developed countries, theoretical research on Internet culture has matured. If we do not catch up with others, we will be more and more backward. In addition, in the six round of online culture research, the relevant research mechanism is still not enough, leading to the lack of strong theoretical support for Internet culture. To sum up, these situations have seriously hindered the development of our university's network culture and the construction of talents [3].

In most universities in China, communication is the main form of teaching activities and publicity activities. Under the current situation of rapid development of Internet technology, many universities are not ready to build their own network platform. In the construction of network culture in Colleges and universities, it is due to the lack of a corresponding network platform, which leads to the lack of effective communication and communication between the network culture construction team and the students. Under such circumstances, students will not be able to establish a comprehensive and systematic understanding of the network culture of their schools. It is precisely because of this problem that students do not understand the network culture of their school at all. In addition, due to the lack of network platform construction, students can not make use of the platform established by the school to share information with each other. Under such circumstances, the construction of network culture in Colleges and universities can not achieve ideal results. In addition, some colleges and universities in China, although the establishment of a new media platform to promote the campus network culture, but its structure and the overall design of the design are relatively rough, and after the completion of the lack of a stable update and maintenance. In this case, the network platform can not make enough attraction for the students 
with the theme of the post-90s generation, and the role it can produce is very limited. In addition to the lack of enough attention to the construction of network culture in Colleges and universities, the lack of high-quality professional network culture construction work team is also an important reason. It can be seen that for the construction of network culture in Colleges and universities, high-quality work teams are indispensable. In view of this, colleges and universities must speed up the pace of construction of the talent team in the construction of network culture, so as to make their own network culture in the true sense of the popularization of the campus [4].

In many colleges and universities in China, network culture construction workers lack sufficient network knowledge and information technology literacy. In addition, colleges and universities have not set up a supporting training mechanism for the already established network culture construction team. In this case, once the network security problems in the campus, the network culture workers can not effectively deal with the problem, can not quickly solve the network security problems. Because of this, there are always a series of problems after entering the campus network culture platform. Over time, they can not afford enough interest in campus network culture. In addition, with the rapid spread of all kinds of network information in the campus, the trend of public opinion on campus is changing all the time. However, in view of these conditions, the campus network culture platform of many universities in China is unable to respond in a timely and effective manner. Under such circumstances, college students prefer to pay attention to new media such as Sina micro-blog and today's headlines, but also do not want to continue to focus on updating the slow campus network. While the students' attention continues to reduce, it will also greatly hurt the enthusiasm of the workers in the network culture construction, which leads to the more insecurity of the updating and timeliness of the campus network.

\section{Several Measures for Strengthening the Construction of Network Culture Working Teams in Colleges and Universities}

In order to ensure the effect of the construction of campus network culture, colleges and universities must cooperate with the Department of education in an all-round way. From the overall situation, the construction of campus network culture and ideological and political education for college students should be placed in the same important position, and on this basis, the construction work of the network culture work team is planned. In the process of building the campus network culture, the leadership of the university must respect the talents, and learn to use the talents and rationally plan the construction of the network culture, so as to ensure the effect of the construction of the network culture. In addition, for every department in the network culture construction institution, university leaders must make reasonable plans and define the powers and responsibilities of various departments. In addition, colleges and universities should increase funds and funds for the construction of network culture on the basis of the present, upgrade and reform the software and hardware facilities of the campus network culture construction institutions, and give appropriate support to their policies. In the process of building the network culture work team, the leaders of colleges and universities must strictly control the selection of talents. After the selection of talents, colleges and universities must conduct regular training to improve their information technology literacy. In terms of treatment, colleges and universities should also appropriately improve the welfare benefits of network cultural work teams so as to improve their enthusiasm and initiative [5].

In many universities in China, there are not only professional network technicians but also part-time teachers and students in the network culture construction team. However, in the specific work, the core of the work must be professional network technicians. In other words, professional network technicians and researchers must occupy a dominant position in the network culture work teams of colleges and universities. Only by such a talent structure can we provide sufficient technical and theoretical guarantee for the construction of network culture. In view of this, colleges and universities must strictly follow the relevant system to select and employ talents when selecting talents for the network culture construction team. In the selection of talents, colleges and universities must adhere to the level of network technology and the knowledge of network culture 
as the main assessment standards, so as to ensure that the personnel in the network culture work team have enough professional quality. For those who do not have enough professional quality, the school must strictly prohibit its entry into the network culture construction work team, thus avoiding the adverse impact on the construction of the network culture.

As a university student, curiosity is inevitable for the campus network culture of his school. However, relying solely on curiosity can not motivate students to explore campus network culture. In fact, many college students are not concerned about their campus network culture at present. The reason is that they do not really realize the importance of the network culture, and have not formed the initiative and initiative to explore the network culture. The main reason for this is that the campus network culture lacks the powerful propaganda means. Even if the students have enough curiosity about the network culture in the campus, they also lack the channels to really understand the network culture. It is precisely because of this that the construction of campus network culture in Colleges and universities needs more efforts to achieve the desired results. In this case, the network culture work team in Colleges and universities must strengthen the propaganda of the campus network culture in the campus, so as to change the students' indifferent thoughts on the network culture and improve the enthusiasm and initiative of the students to participate in the construction of the network culture. In addition, increasing publicity on Internet culture can enhance students' awareness of Internet culture and effectively improve the construction process of Internet culture. In addition, the Propaganda Group for Internet culture in Colleges and universities must be persevere, thus ensuring the continuity of the campus network culture, and ensuring the sustainability and stability of the network culture construction [6].

\section{Summary}

With the rapid development of Internet information technology, people's work and life are increasingly inseparable from the Internet. In Colleges and universities, college students are more receptivity to the Internet. For today's college students, the Internet has become an important part of their lives. Therefore, we must pay attention to the guiding role of Internet culture for college students' ideology. However, because of the complexity of network environment and the complexity of network information, students are easily influenced by unhealthy network culture. Under such circumstances, in order to protect the students' world view from the influence of garbage network information, it is imperative for the university to build its own network culture. In the end, all kinds of problems in the network construction of our universities are caused by the immature construction of all kinds of network culture. In view of this, this article puts forward several measures to strengthen the construction of various teams in the network culture, hoping to provide useful help for the construction of network culture in Colleges and universities.

\section{Acknowledgements}

Research Fund Project: Research on the Construction of Network Culture Work Team in Universities. Numbering: 2017SZ18 (The Research Fund Project of Shaanxi University of Chinese Medicine)

Research direction: ideological and political education

\section{References}

[1] Jia L I, University N N. Research on the Innovation of Management Work and the Construction of Campus Culture in Higher Colleges[J]. Journal of Hubei Correspondence University, 2017.

[2] Liu X, Xia X. Research on the Construction of College Network Culture from the Perspective of Inclusive Development[J]. Journal of Chuzhou University, 2016.

[3] Peng R, Bing Q. Research to Construction of Laboratory Culture in Colleges and Universities under a New Situation[J]. China Educational Technology \& Equipment, 2017. 
[4] Wang Y, Li Z, University N X. Research on reading promotion and campus culture construction of universities and colleges in the new media age[J]. Wireless Internet Technology, 2017.

[5] Na L I, Zhang X T. Research on the construction of campus culture in modern colleges[J]. Journal of Hunan City University, 2016.

[6] Dong G, Jianwu Q U. Research on the Problems and Countermeasures to the Construction of Dormitory Culture in Universities[J]. Journal of Shenyang Jianzhu University, 2017.

The first author: Xing Nian, Female, Shaanxi Province, October 10th, 1982. Master degree, lecturership, Full-time counselor 